\title{
İleri Dönüşümlü Ambalaj Tasarımlı Ürünlere Yönelik Tüketici Tutumu ve Satın Alma Niyeti İlişkisi*
}

\author{
The relationship between consumer attitude towards upcycled product \\ packaging design and purchasing intent
}

\author{
Hatice ARSLAN 1 \\ Süleyman BARUTÇU ${ }^{2 a}$
}

\begin{abstract}
${ }^{1}$ Dunapack Dentaş Ambalaj, Denizli. hatice.arslan@dunapack-packaging.com 2 Pamukkale Üniversitesi, İktisadi ve İdari Bilimler Fakültesi, Denizli. sbarutcu@pau.edu.tr a Yazışılan yazar/Corresponding author
\end{abstract}

\begin{abstract}
Özet
Ambalaj, ürünü koruma fonksiyonu yanında tüketiciye etki etmesi ve ürünü diğer ürünlere göre daha tercih edilir kılmasında önemli bir araçtır. Bu nedenle, ambalaj tasarımlarında müşteri için bir değer ifade edecek şekilde ve müşteriye fayda sağlaması amaçlanarak yapılan yenilikler, pazarlama çabalarına destek olma yanında işletmelerin rekabet avantajı sağlamasında da önemli bir araç olarak karşımıza çıkmaktadır. Önemli yenilik alanlarından biri de ileri dönüşümdür. İleri dönüşüm, ömrü biten ambalaja yeni bir işlev ekleyerek adeta ölümden sonra yaşam veren yeni bir yaklaşımdır. Bu çalışmada yenilik ve ambalaj tasarımında yenilik çerçevesinde ileri dönüşüm kavramı açıklanmış ve tüketicilerin ileri dönüşümlü ambalajlara yönelik tutumu ve satın alma niyeti ilişkisi analiz edilmiştir. 253 kişi üzerinde yapılan tanımlayıcı araştırma sonuçlarına göre; katılımcıların ileri dönüşümlü ambalajlara yönelik olumlu bir tutum gösterdiği ve çevreye ilişkin bilgi ve çevreye ilişkin kişisel değerlerin ileri dönüşümlü ambalaja sahip ürün satın alma niyeti arasında pozitif yönlü bir ilişki bulunduğ u belirlenmiştir.
\end{abstract}

Anahtar kelimeler: Yenilik, Ambalaj tasarımı, İleri dönüşüm, Sürdürülebilirlik

JEL kodları: M31, M11, Q56.

\begin{abstract}
Besides the product protection function, packaging is an important tool for the consumer to influence and make the product more preferable than other products. For this reason, innovations in packaging designs aimed at expressing value for the customer and aiming to provide benefit to the customer appear to be an important tool in providing competitive advantage for business as well as supporting marketing efforts. One of the important areas of innovation is upcycling (advanced transformation in packaging). Upcycling is a new approach that gives life after death by adding a new function to the end-of-life package. In this study, the concept of upcycling in innovation and innovation in packaging design are explained and the relationship between consumer attitude and purchase intention on upcycled packaging are analyzed. According to the descriptive research results of 253 respondents; It was determined that the participants showed positive attitudes towards the upcycle packaging and there was a positive relationship between the environmental information and the environmental values and the intention of purchasing the product with the upcycled packaging.
\end{abstract}

Keywords: Innovation, Packaging design, Upcycling, Sustainability

JEL codes: M31, M11, Q56.

\footnotetext{
* Bu çalışmanın özeti “XIII. International Balkan and Near Eastern Congresses” adlı kongrede sunulmuştur (5-6 Ekim 2019, Tekirdağ).
} 


\section{GİRIŞ}

Yaşanan teknolojik gelişmeler ve sanayileşme, çevreye zarar vermekte, doğal kaynakların tükenmesine sebep olmaktadır. Son zamanlarda, tüketicilerin çevre ile ilgili bilgisinin artması ile çevreci ürünlere olan talebi de olumlu yönde etkilemiştir. Tüketicilerin bu yaklaşımları, işletmelerin de bu konuda sorumluluklarını arttırmakta ve ürün hayat döngüsü süresince ekolojik önlemler almaya ve çevreci stratejiler geliştirmeye zorlamaktadır. Bununla beraber, işletmelerin yoğun rekabet ortamında fark yaratabilmek için uyguladıkları çevre dostu stratejiler, ürünlerin ambalaj tasarımlarında da yenilikçi yaklaşımlar ile kendini göstermektedir.

Ambalaj tasarımlarında yapılan çevreci ve sürdürülebilirliğe katkı sağlayan yenilikler, ürünü rakiplerinden ayırarak, tüketicinin dikkatini çekmesini de amaçlamaktadır. Bu hususta; ambalaj malzemesinin çevreye zarar vermeyecek şekilde seçilmesi, ambalaj üretimi esnasında çevreye minimum zarar verilmesi, ambalajın geri kazanılması, ambalajın geri dönüştürülebilir olması veya yeniden kullanılması gibi stratejiler öne çıkmaktadır. Bu kavramların ötesinde, kullanım ömrü biten ambalaja tüketicinin yeni bir işlev kazandırarak, ambalajın farklı bir amaçla yeniden kullanılabilir olması ise ileri dönüşüm kavramı ile açıklanabilmektedir.

Son günlerde ileri dönüşüm kavramı ile ürün ambalajında kendini gösteren pazarlama yenilikleri, genellikle tüketici için bir değer ifade etmekte ve kullanıcıların hayatlarında bir değişikliğe sebep olmaktadır. Ekonomik, sosyal ve çevresel bir fayda oluşturmayı da amaçlayan bu tip ambalaj yeniliklerinin işletmeler açısından da pazarda yenilikçi bir rekabet avantajı olarak ortaya çıkması beklenmekte, araştırma sonuçları bu hususta ele alınmaktadır. Bu bağlamda çalışmanın kavramsal çerçeve bölümünde yenilik, pazarlamada yenilik, ambalaj, ambalaj tasarımında yenilik, çevre bilinci ve sürdürülebilirlik ve ileri dönüşüm kavramları açılanmış, araştırma bölümünde ise ileri dönüşüme yönelik tutum ve bu tutumun satın alma niyetine etkisi belirlenmiştir.

\section{KAVRAMSAL ÇERÇEVE}

\subsection{Yenilik Kavramı ve Pazarlamada Yenilik}

Yenilik, firmalar için rekabet üstünlüğü elde edilmesinde oldukça önemlidir (Bülbül, 2003: 114). Yenilik kavramı literatürde ürün yenilikleri, süreç yenilikleri, pazarlama yenilikleri ve organizasyonel yenilikler olarak 4 ayrı sinıfta incelenmektedir. Yenilik, Oslo kılavuzunda ise “işletme içi uygulamalarda ve organizasyonunda veya dış ilişkilerde yeni veya önemli derecede iyileştirilmiş bir ürün (mal veya hizmet), veya süreç, yeni bir pazarlama yöntemi ya da yeni bir organizasyonel yöntemin gerçekleştirilmesi" olarak tanımlanmaktadır. Ürün yeniliği, var olan özellikleri ve mevcut kullanım fonksiyonlarına göre yeni veya geliştirilmiş bir mal veya hizmetin oluşturulması; tasarım ise ürüne yenilik getirebilmesi ve bu yeniliklerin uygulanması anlamında sürecin önemli bir bileşeni olarak tanımlanmaktadır (OECD, 2005: 50-52).

Tüketiciler için ise yenilik, kullandıkları ürün ve hizmetlerin değişmesi ve iyileşmesidir. Oluşturulan bu değişikliklerin ve iyileşmelerin yaşam kalitesini arttırması, kullanıcıların yaşamlarında değişiklik yapması, sosyal ve ekonomik fayda sağlaması önemlidir. Sağlanan yenilikler tüketiciler için bir değer ifade etmelidir (Altunışık vd., 2016: 340-341). Yenilik kavramı tüketicilerce olumlu algılandığında pozitif çağrışımlara da yol açmaktadır. 
Müşteriler, ürün alırken yenilikçi ürün alma eğilimde olurken fiyatın daha pahalı olmasını göz ardı edebilmektedirler (Uyar, 2015: 174).

Pazarlama yeniliği, ürün tasarımı veya ambalajı, konumlandırma, pazarlama iletişimi veya fiyatlandırmada yapılan değişikliklerden oluşur ve daha önce uygulanmamış bir pazarlama yöntemini ifade eder. Pazarlama yenilikleri günümüzde müşteriyi merkeze alan bir yaklaşım ile oluşturulmakta; pazarlama bileşenlerinin her birine ayrı ayrı etki etmektedir. Firmalar, müşterilerin taleplerini karşılayabilmek amacıyla ürün ya da ambalajda inovatif tasarımlar geliştirmekte, farklı pazarlama yöntemleri geliştirerek rakiplerinden farklılaşmakta, teknolojinin gelişmesi ile yeni ve farklı dağıtım kanalları oluşturmakta ve böylece müşterilerine daha yüksek bir değer sunma eğilimindedirler. Bu sayede aynı işi yapan işletmelerden farklılaşarak rekabet avantajı sağlayabilmektedirler (Elçi, 2007: 12). Pazarlama yenilikleri, ürün tasarımındaki yenilik ve gelişmeleri de kapsamaktadır. Tasarımdaki değişimler, sadece ürün formu ve diş görünüşündeki değişiklikleri değil, ambalajın ürün kadar önemli olduğu gıda, içecek, deterjan gibi ürünlerin ambalajlarındaki inovasyonları da içerir. Bu kapsamdaki yenilikler, hem mevcut ürün fonksiyonlarının hem de ürünün ambalajlanmasının bir arada iyileştirilmesi anlamına gelerek, hem ürün hem de pazarlama yenilikleri olarak ifade edilmektedir (OECD, 2005: 58). Ambalaj tasarımında yapilan yenilikler, ambalajın fonksiyonları ile birlikte ele alındığında pazarlamanın her bir bileşenine etki etmekte, bu sebeple ambalajın ürün kadar önemli olduğu sektörlerde faaliyet gösteren işletmeler için önem arz etmektedir.

\subsection{Pazarlamada Ambalaj ve Ambalaj Tasarımında Yenilik}

Ambalaj; ürün dizisindeki maddenin veya ürünün içine konulduğu bir kap, sarmalık veya konteynerdir. Ürünün içeriğini ve çevresini koruyan, taşıma ve depolanmasını, satışını, kullanılmasını kolaylaştıran, ileride kısmen veya tamamen atılabilecek veya geri dönüşümlü bir malzemeyle kaplanması, sarılması, örtülmesi ya da birleştirilmesidir (Tek, 1999: 372). Geçmişte ambalajlama, üretim maliyetine ek bir yük getiren üretim sürecinin bir parçası olarak kabul edilmekte iken, günümüzde ürün geliştirme aşamasından başlayıp pazarın ihtiyaçlarına göre tasarlanmasından, üretim, koruma, depolama, taşıma, dağıtım, reklâm, satış ve son kullanıma kadar her aşamada önemli bir araç haline gelmiştir. Kısaca ambalaj, yalnızca içine konan ürünü koruyan bir tamamlayıcı araç değil, ürünün bir parçası (Üçüncü, 2000:4) ve günümüzde etkili bir pazarlama aracı olarak karşımıza çıkmaktadır. Tüketiciler için kolaylık sağlayan akıllıca tasarlanmış bir ambalaj, aynı zamanda işletmelerin promosyon faaliyetlerine de katkı sağlayabilmektedir (Aygün, 2007: 5). Ambalajın, pazarlama karmasının elemanları üzerine önemli etkileri bulunmaktadır. Ambalajın ürünü farklılaştırması, pazarı bölümlendirmesi, ürünün miktar ve boyutunu belirlemesi ile ürüne etki etmesi, ambalaj maliyeti ve miktar ile ürünün nihai fiyatına etki etmesi, tüketiciye mesaj iletmesi ve tüketiciyle iletişim kurarak tutundurma fonksiyonuna etki etmesi, sevk esnasında da koruma, taşıma, depolama özeliklerini belirlemesi ile dağıtıma etkisi büyüktür. Ambalajlama stratejilerinin hem pazarlama karmasının $4 \mathrm{P}^{\prime}$ si ile hem de markanın ve firmanın sahip olduğu strateji, vizyon ve temel değerleri ile örtüşmesi beklenmektedir. Örneğin, ambalaj, alışveriş sonrasında da promosyon görevi yapabilir, çünkü yeniden kullanılan ambalajlar ürünün sabit birer hatırlatıcısıdır (Kotler, 1988: 284, akt. Erkınay, 1996: 14). 
Ambalajın tutundurmayı sağlayan 3 temel fonksiyonu; tüketiciye etki, firma ve marka imajına etki ve yenilik getirmenin sağladığ fırsatlardır. Tüketiciye etki ile anlatılmak istenen; ortak özelikler içeren ürünlerin ambalajlarındaki farklılığın tüketiciye etki etmesi ve ambalaj sayesinde ürünü diğerine göre daha tercih edilir kılmasıdır. Firma ve marka imajına etki ile anlatılmak istenen; markanın en önemli özelliğinin şirketin rakiplerinden farklılıklarını ve imajını ifade eden unsur olması ile bağlantılı olarak, ambalajın da marka ve şirket stratejileri ve görüşleri ile ters düşmemesi ve aynı dili konuşması gerekliliğidir. Yenilik getirmenin sağlayacağı fırsatlar ise yeni teknolojilerin kullanımı gibi ambalajı oluşturan unsurlarda

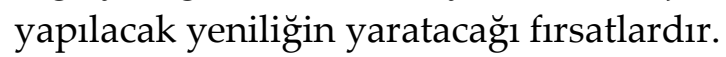

Ambalaj tasarımında yenilik, ürün ambalajının değiştirilip geliştirilerek tüketiciye bir yenilik götürülebilmesi şeklinde değerlendirilebilir. Ambalajda yapılan yenilikler ürün performansını da pek çok yolla geliştirebilir. Kullanılan ürün miktarlarının değiştirilmesi, depolama ve sevkiyat için yapılan yenilikler, kolay taşıma ve ürün güvenliğini arttırıcı ambalajlama yenilikleri bunlara örnek gösterilebilir (Arköse, 2004: 113). Bunların yanında, ambalaj tekniklerindeki teknolojik gelişmeler ve iyi bir ambalaj tasarımı sonucunda ortaya çıkan estetik ve fonksiyonel özellikler, ambalajı müşterinin fazla fiyat ödeyebileceği bir unsur olarak karşımıza çıkarmıştır. Birçok sektörde kendini gösteren bu durum, üreticilerin ürünle aynı derecede ambalaja da önem vermeleri gereğini ortaya koymuştur (Şen, 2007: 3).

\subsubsection{Ambalaj Tasarımı ve Ambalaj Tasarımlarının Fonksiyonları}

Ambalaj, kullanım alanına göre 3'e ayrılmaktadır. Bunlar birincil ambalaj (iç ambalaj), ikincil ambalaj (dış ambalaj) ve yükleme (nakliye) ambalajıdır. Ambalajlanan ürünle doğrudan temas halinde bulunan ambalaja iç ambalaj (birincil ambalaj), iç ambalajdaki mamulün bir ya da daha çok birimini bir arada tutan ambalaja da ikincil ambalaj (diş ambalaj) denmektedir. Tüketici ile ilişki kuran ve satın alma davranışlarını etkileyebilecek olan ambalaj, birincil ve ikincil ambalajlardır (Aygün, 2007: 8). Ambalajın işlevleri 5 ayrı sınıfta incelenebilmektedir. Bunlar, ambalajın koruyuculuk işlevi, taşıma, açma kapama ve depolamayı içeren kolaylık işlevi, ambalajın fiyat ayarlama işlevi, ambalajın bilgi verme ve iletişim işlevi, ambalajın grafik tasarım, şekil, renk ve baskıyı içeren görsel işlevleridir.

Ürün ambalajının fonksiyonlarına yönelik farklı araştırmacıların görüşleri Tablo 1'de sunulmuştur. 
Tablo 1. Ürün Ambalajının Fonksiyonuna Yönelik Yaklaşımlar

\begin{tabular}{|c|c|}
\hline $\begin{array}{c}\text { Brennan ve } \\
\text { diğerleri (1990) }\end{array}$ & $\begin{array}{l}\text { Bir malzeme taşıma aracı; prosese yardımcı; kolaylık sağlayıcı öğe; bir pazarlama aracı; } \\
\text { maliyet tasarrufu sağlayan bir alet; ürünün koruyucusu }\end{array}$ \\
\hline $\begin{array}{l}\text { Copley } \\
(2004)\end{array}$ & $\begin{array}{l}\text { Marka değerlerini ve imajlarını ifade eden bir araç; estetik olarak hoş; güçlü görsel etki; } \\
\text { öne çıın, diğer markalardan dikkat çekerek farklılaşın ve dikkat edin; markanın ne } \\
\text { anlama geldiğinin canlı bir ifadesi; bir değer arttırıcı; markanın bir hatırlatıcısı; ipuçları } \\
\text { sağlayıcı; hedefle duygusal bir bağlantı sağlayıcı. }\end{array}$ \\
\hline $\begin{array}{l}\text { Blythe } \\
(2005)\end{array}$ & $\begin{array}{l}\text { Müşterileri bilgilendirir. Yasal bilgi gereksinimlerini karşılar. Bazen ürünün kullanımına } \\
\text { yardımcı olur (örneğin, içecek kutularına halka çektirmek, kutuyu açmayı kolaylaştırır). }\end{array}$ \\
\hline & $\begin{array}{l}\text { Kırılgan ürünleri korur; hasara karşı kalkan oluşturur; sızıntıları önler; malları dağıtır; } \\
\text { güvenlik ve hijyen sağlar; israfı azaltır; bilgi iletir; mevzuatı karşılar; maliyetleri düşürür; } \\
\text { tüketicilerin bir seçim yapmalarını sağlar; hırsızlığı azaltır. }\end{array}$ \\
\hline $\begin{array}{l}\text { Grundey'in } \\
\text { Yaklaşımı }\end{array}$ & $\begin{array}{l}\text { 1) Bir ürünün tanıtımını yapmak ve satmak } \\
\text { 2) Prestij, rahatlık veya statü kazandırarak ürün ve marka kimliğini tanımlamak ve } \\
\text { konumlandırmak } \\
\text { 3) Çeşitli taşıma sembolleri, etiketleme, içerik, garantiler, besin değeri, potansiyel } \\
\text { tehlikeler dahil olmak üzere bilgi sağlamak } \\
\text { 4) Farklılaştırılmış boyutlar, şekiller, geri dönüştürülebilirlik fırsatları vb. içeren müşteri } \\
\text { ihtiyaçlarını karşlamak } \\
\text { 5) Cam kaplar yerine plastik, plastik kaplar yerine karton, emniyet korumalı ambalaj, } \\
\text { blister ambalajlar, çocuklardan korumalı kaplar } \\
\text { 6) Nakliye, depolama ve teşhir sırasında koruyucu ambalajlar sunar } \\
\text { 7) Yiyecekleri bozulmadan korur } \\
\text { 8) Gıdaları uzun süre soğutmadan taze tutan bir teknolojiyi içeren steril ambalajı } \\
\text { desteklemek } \\
\text { 9) Ambalajın çevre versiyonları için yeniden kullanılabilir, geri dönüştürülebilir, daha az } \\
\text { atık, biyolojik olarak parçalanabilir ve daha güvenli uygulayarak çevresel / çevreyle ilgili } \\
\text { ambalajlamayı teşvik eder } \\
\text { 10) Sosyal ya da politik nedenler gibi ürün dışı konuları teşvik ederek, örneğin ambalajın } \\
\text { üzerine sloganlar koyarak: “Çocukları kurtar”, "Dünyayı besle”, "Haiti - lütfen ver” gibi } \\
\text { sebeplerle ambalajlama seçeneklerinin desteklenmesi }\end{array}$ \\
\hline
\end{tabular}

Kaynak: Grundey (2010: 87-103)

Ambalajın fonksiyonları, yukarıdaki tabloda farklı araştırmacıların yaklaşımlarından da görüleceği gibi yıllar içerisinde değişmiş ve ambalajın temel fonksiyonlarının yanına iletişim, prestij, statü gibi sosyal ve ekonomik açıdan da yeni değerler eklenmiştir.

Ambalajın koruma, fayda ve iletişim fonksiyonları göz önüne alınarak insan, biyosferik ve fiziksel açıdan taşıdı̆̆ı anlamlar ise Tablo 2'de verilmiştir. Örneğin, ambalajın koruma fonksiyonu insan ile ilişkilendirildiğinde ambalajın içerisindeki ürünü herhangi bir tüketicinin yanlış kullanımından koruması ifade edilmektedir. Asidik temizlik ürünlerin ambalajlarında kullanılan presleme kapakları bu korumayı sağlamaktadır. Koruma fonksiyonunun biyosferik açıdan taşıdığı anlam ise ambalaj malzemesinin dış çevre koşullarından etkilenmeyecek şekilde seçilmesi sayesinde içindeki ürünü korumasıdır. Koruma fonksiyonunun fiziksel açıdan taşıdığı anlam ise ürünün depolanma ve nakliye esnasında zarar görmeyecek şekilde ambalajlanması; gerektiğinde ambalaj içinde korumalı, hava kabarcıklı takviye malzemeler kullanılmasidır.

Ambalajın fayda fonksiyonu insan ile ilişkilendirildiğinde kolay ve işlevsel paketleme, tüketicinin kullanımına uygun boyut seçimi ifade edilmektedir. Ambalajın biyosferik açıdan faydası ile ürün ambalajlarında doğaya zarar vermeyen malzeme seçimi ifade edilmektedir. 
Fayda fonksiyonunun fiziksel açıdan taşıdığı anlam ile ambalajın rahat taşınması için kullanılan ek tutamaklar veya ısıdan, soğuktan korumalı ambalajlar ifade edilmektedir.

Ambalajın iletişim fonksiyonu insan ile ilişkilendirildiğinde ambalajın üzerindeki etiket, son kullanma tarihi gibi bilgiler sayesinde tüketici ile iletişime geçilmesi ifade edilmektedir. Ambalajın nasıl elden çıkarılacağı gibi biyolojik uyarı ve açıklamalar biyosferik iletişim ile ifade edilmektedir. Ambalaj üzerindeki kırılgandır, dikkatli kullanın gibi resimli uyarılar ise ambalajın fiziksel iletişimi ile ifade edilmektedir.

Tablo 2. Ürün Ambalajı Matrisi

\begin{tabular}{|c|c|c|}
\hline A1 koruma-insan & B1 fayda-insan & C1 iletisim-insan \\
\hline $\begin{array}{l}\text { Kendiliğinden açılan şişeler, } \\
\text { teneke kutular, kartonlar ve } \\
\text { kaplar. } \\
\text { Çocuk korumalı ambalajlama } \\
\text { Özellikleri; ilaç } \quad \text { kapları } \\
\text { üzerindeki } \\
\text { kapakları. }\end{array}$ & $\begin{array}{l}\text { Şekil. Boyut. } \\
\text { Ambalaj malzemelerinin dokusudur. } \\
\text { Ürün tazeliğini korumak için açması ve } \\
\text { yeniden paketlemesi kolaydır. } \\
\text { Uyumlu paketleme. } \\
\text { Marka konumlandırma. }\end{array}$ & $\begin{array}{l}\text { Markalar (logo, isim, grafik). } \\
\text { Etiketleme bilgileri (uyarılar, son } \\
\text { kullanma tarihi, içerikler) } \\
\text { Şekil (örn. Ayıcıklı şişelerde bal). } \\
\text { Boyut. } \\
\text { Renk. }\end{array}$ \\
\hline A2 koruma-biyosferik & B2 fayda-biyosferik & C2 iletişim-biyosferik \\
\hline $\begin{array}{l}\text { UV ışınlarına karşı yüzey ve } \\
\text { renk seçimi. } \\
\text { Oksijen önleyici malzemeler. } \\
\text { Su ve nem önleyici / istinat } \\
\text { paketlemesi. } \\
\text { Anti-mikrobiyal paketleme. }\end{array}$ & $\begin{array}{l}\text { Su ve nem önleyici / istinat } \\
\text { paketlemesi. } \\
\text { Atmosferik gereklilikler nedeniyle } \\
\text { ambalajın değiştirilmesi. }\end{array}$ & $\begin{array}{l}\text { Zaman ve sıcaklık göstergeleri/ } \\
\text { işaretleri. } \\
\text { Biyolojik uyarılar için resimli } \\
\text { açıklamalar (özellikle ambalajın } \\
\text { nasıl elden çıarılacağı } \\
\text { konusunda). }\end{array}$ \\
\hline A3 koruma-fiziksel & B3 fayda-fiziksel & C3 iletișim-fiziksel \\
\hline $\begin{array}{l}\text { Nakliye paketleme. } \\
\text { Konforlu / korumalı, hava } \\
\text { kabarcıklı / hava yastıkları. } \\
\text { Yığınlar için güçlü ambalaj } \\
\text { kağıtları }\end{array}$ & $\begin{array}{l}\text { Ambalajın fiziksel değişiklikleri } \\
\text { (küçültme / genişletme). } \\
\text { Isı / soğuk koruma ambalajı. } \\
\text { Farklı boyutlu ambalajları taşımak için } \\
\text { ek tutamaklar. } \\
\text { Rahat taşıma, sarma vb. için } \\
\text { tasarlanmış kılıflar } \\
\text { Dondurulmuş-çok amaçlı kullanım } \\
\text { için ayarlanmış paketleme (ya üst filmi } \\
\text { çıkararak ya da filmi bir çatalla atarak } \\
\text { vb.) }\end{array}$ & $\begin{array}{l}\text { Barkodlar (ürün ve fiyat } \\
\text { tanımlaması için). } \\
\text { Ambalajlama konusunda resimli } \\
\text { uyarılar (bu taraf yukarı, kırılgan, } \\
\text { dikkatle kullanın, sıcaklık } \\
\text { göstergeleri). }\end{array}$ \\
\hline
\end{tabular}

Kaynak: Grundey (2010: 87-103)

Gelişen ve değişen dünyada farklı fonksiyonlar ve değerler yüklenen ambalaj tasarımlarının müşteri odaklı, ürün odaklı, çevre odaklı ve yenilikçi bir bakış açısı ile yaratılması, hem tüketiciler için hem işletmeler için hem de daha yaşanabilir bir çevre için fayda sağlayacaktır.

\subsubsection{Yenilikçi Ambalaj Tasarımları}

Yapılan literatür taramaları sonucunda varılan sonuca göre ambalaj, ürün satın alınmasına etki edebilecek, aynı zamanda ürünün imajına yön veren, ürünün tutundurulmasına ve farklı kılınmasına etki edebilecek bir pazarlama aracı olarak değerlendirilmektedir. Tüketicinin satın alma sırasında rafta gördüğü ürünler arasından kısa süre içerisinde tercih yapması gerektiğinde, ambalajın bu konuda yarattığı değer önem taşımaktadır (Erkınay, 1996: 18). 
Yeni bir ürün, yenilikçi bir ambalaj tasarımı ile rafta yerini aldığında, rakiplerinden ayrılabilmektedir. Yaratıcı bir ambalajlama, ürünün pazarda iyi bir şekilde konumlanmasına da yardımcı olabilmektedir. Yenilikçi ambalaj tasarımını etkileyen birçok etmen bulunmaktadır. Bunlardan bazıları; yeni teknolojiler, malzeme özellikleri, lojistik gereklilikleri, depolama ve sevkiyat koşulları, tüketici tercihleri, pazarlamacıların bakış açıları olarak sıralanabilir. Farklı ürünler için farklı ambalaj tasarımı stratejileri izlenebilir. Ambalaj üzerinde yapılacak olan yeniliklerin tüketici tarafından "yeni" ve "değişik" olarak algılanması, ürünün arzu edilebilirliğini arttırıcı etki yapmaktadır. Fakat bu değişikliklerin geri tepme riski de olduğundan dikkatli ve uygun seçimi yapmak önemlidir (Erkınay, 1996: 43).

Yenilikçi ambalaj tasarımlarında farklı yenilik alanları bulunmaktadır. Bu çalışmada ise sadece ambalajda ileri dönüşüm ile getirilen yenilikçi özellikler incelenmiştir. Bu kapsamda öncelikle ambalajın çevre ve sürdürülebilirlik kavramları ile ilişkisi ele alınmıştır.

\subsection{Ambalaj ve Çevre}

Ambalaj ve çevre ilişkisi göz önüne alındığında, iyi tasarlanmış bir ambalajın çevre duyarlılığı ve sürdürülebilirlik kavramları ışı̆̆ında geliştirilmiş olması beklenmektedir. Bu hususta ambalajın üretiminde daha az kaynak kullanılması, daha az malzeme ve enerji harcanması gerekmektedir. Tekrar kullanılabilme olanağının düşünülmesi, geri dönüştürülme ve geri kazanım konularının da tasarım aşamasından itibaren değerlendirilmesi gerekmektedir (Ambalaj Bülteni, 2010: 1). Geri kazanım; ambalaj atıklarının, fiziksel, kimyasal ve biyolojik yöntemlerle bazı işlemlerden geçirilmek suretiyle geri dönüştürülmesini, yakılarak enerji elde edilmesini ifade etmektedir. Geri dönüşüm ise ambalaj atıklarının bir üretim süreci içerisinde esas amacı veya başka bir amaç için, organik geri dönüşüm dâhil, enerji geri kazanımı hariç olmak üzere yeniden işlenmesidir (Ambalaj Atıklarının Kontrolü Yönetmeliği, 2017). Yeniden kullanım ise; ürünlerin, yalnızca toplama ve temizleme işleminden geçirilerek, mevcut haliyle ekonomik ömrü dolana kadar pek çok kere kullanılması anlamına gelmektedir. Yeniden kullanım işlemi birçok alanda uygulanmakta ve işletmelere çok ciddi maliyet avantajları kazandırmaktadır. Cam şişelerin ve su damacanalarındaki suyun tüketildikten sonra temizlenip tekrar aynı veya farklı amaçlar için kullanılması buna örnek verilebilir.

Ambalaj atıklarının yeniden kullanımı, hem ekonomik olarak yeni bir girdi yaratmakta hem de atık miktarlarının azaltılması anlamında tasarruf sağlamaktadır (Özesen, 2009: 32). Ambalajın tasarımı aşaması dâhil olmak üzere; üretim, satış, dağıtım ve satış sonrasında da yeniden kullanılabilir ve/veya belirli bir oranda geri dönüşebilir nitelikte olması ambalajın çevre açısından önemini ifade etmektedir. İyi yapılmış olan ambalajlama, ürünlerin bozulmasını önlediği için israfı azaltmakta, aynı zamanda atık miktarını azalttığı için çevreye katkı sağlamaktadır. Bu anlamda sürdürülebilir bir yaşam ve sürdürülebilir çevre için ambalajda tasarım kriterleri de zamanla bu değişime uyum sağlamaya başlamıştır.

\subsection{Ambalaj ve Sürdürülebilirlik}

Dünya sürdürülebilir gelişme komisyonunda sürdürülebilir gelişme; “bugünün ihtiyaçlarına, gelecek neslin ihtiyaçlarına ulaşmasına engel olmadan ulaşma" şeklinde tanımlanmıştır (Bruntland, 1987; akt. Özgen, 2013: 69). Bu tanıma daha sonra eklenen ekonomik refah, çevre kalitesi ve sosyal adalet kavramları sürdürülebilir kalkınmayı ifade ederken, yıllar içerisinde 
bu tanım genişleyerek gerçekleştirilen faaliyetlerin süreklilik kazanması ile bu sürekliliğin nasıl sağlanabileceği ile ilgili plan ve programların geliştirilmesi anlamını kazanmıştır. Bu sayede farklı alanlarda kullanımı artmış, sürdürülebilir turizm, sürdürülebilir tüketim, sürdürülebilir yaşam, sürdürülebilir tüketim ve sürdürülebilir sosyal medya pazarlaması gibi süreklilik arz eden kavramlar ortaya çıkmıştır (Barutçu ve Tomaş, 2013: 11). Sürdürülebilir ambalaj tanımı ise literatürde kendine yeni yeni yer bulurken, son yıllarda yapılan çalışmalar sayesinde bu konuda bazı kriterler belirlenebilmiştir. IAPRI (International Asssociation of Packaging Research Institutes) 2004 konferansının sonucuna göre, sürdürülebilir ambalaj tasarımı için ürünler Tablo 3'deki kriterlere uymalıdır (James vd., 2005). Buna göre sürdürülebilir ambalaj, sosyo ekonomik amaçlara erişmeyi sağlayacak şekilde verimli; malzeme kullanımı, enerji ve suyun mümkün olduğunca verimli kullanımı konularında amaçlara erişmeyi sağlayacak şekilde etkili; endüstriyel ve çevresel sistemler içinde dönüştürülebilir olacak şekilde döngüsel, ekosistemi kirletmeyecek ve zehirli olmayacak şekilde güvenli olmalıdır.

Tablo 3. SPA (Sustainable Packaging Alliance) 'nın Sürdürülebilir Ambalaj Tanımı

\begin{tabular}{|c|c|c|}
\hline İlke & Açıklaması & İlkenin Uygulanacağı Seviyeler \\
\hline Etkili & $\begin{array}{l}\text { Bilinçli ve sorumlu tüketime destek } \\
\text { olarak ve ürünleri tedarik } \\
\text { zincirinde etkili bir } \\
\text { koruyup kapsayarak topluma } \\
\text { gerçek değeri katar. }\end{array}$ & Toplum \\
\hline Verimli & $\begin{array}{l}\text { Ambalaj sistemleri ürünün yaşam } \\
\text { çevrimi boyunca malzeme ve } \\
\text { enerjiyi mümkün olduğunca çok } \\
\text { verimli kullanmak üzere } \\
\text { tasarlanmiştır. }\end{array}$ & Ambalaj Sistemi \\
\hline Döngüsel & $\begin{array}{l}\text { Ambalaj malzemeleri malzeme } \\
\text { indirgenmesi ve katkı maddesi } \\
\text { gelişimiyle sürekli olarak doğal ve } \\
\text { teknik sistemlerle çevrilir. }\end{array}$ & Ambalaj Malzemesi \\
\hline Güvenli & $\begin{array}{l}\text { Ambalaj parçaları insan sağlığı ve } \\
\text { ekosistem için risk oluşturmaz. }\end{array}$ & Ambalaj Parçaları \\
\hline
\end{tabular}

Kaynak: James vd. (2005)

SPC (2006)'ya göre ise sürdürülebilir ambalaj tasarımı; (1) ürün, hayat döngüsü boyunca ürünü kullanan tüketiciler ve toplum için güvenli ve sağlıklı olması, (2) performans ve fiyat ile ilgili piyasanın taleplerini karşılaması, (3) üretim, dağıtım, geri dönüştürülmüss malzeme kaynağı vb. konularında yenilenebilir enerji kullanılması, (4) maksimum miktarda geri dönüştürülmüş materyal kullanılması, (5) çevreye duyarlı üretim yöntemleri ve uygulamaları seçilmesi, (6) fiziksel olarak malzeme ve enerji kullanımını dengelemesi, ve (7) yeniden kullanılabilir ve iyileştirilebilir özellikte olması şeklinde sıralanabilir.

Sürdürülebilir gelişim ile ilgili çalışmalar, aynı zamanda "yeşil pazarlama” kavramını ortaya çıkarmıştır. Yeşil pazarlama, tüketicilerin taleplerini karşılarken ekosisteme verilen zararın olabilecek en düşük seviyede kalmasını sağlayacak şekilde gerçekleştirilen faaliyetlerin tamamıdır (Karaca, 2013; akt. Övünç, 2015: 19). Tüketiciler, doğa için zararsız ürünleri satın alarak, yalnızca bugünü değil geleceği de hesaba katarak satın alma davranışı göstererek, 
atıklarını azaltarak, geri dönüşüm ve tekrar kullanım sürecine katkı sağlayarak, kısacası bir "yeşil tüketici" gibi davranarak çevre kirliliğinin azaltılmasına destek olabilirler (Türk, 2019).

Ambalajın çevre ve sürdürülebilirlik kavramları ışı̆̆ında kazandığı tüm bu değerler ve işletmeler için uyum sağlanması önemli olan ambalaj tasarım kriterleri, hem tüketiciler ve işletmeler için hem de daha iyi yaşanabilir bir dünya için günden güne daha çok önem kazanmaktadır. Ambalajın sürdürülebilirliğine katkı sağlayabilecek, işletmeler için rekabet avantajı sağlayabilecek, yenilikçi bir ambalaj tasarım kriteri olarak karşımıza çıkabilecek olan ambalajda ileri dönüşüm özelliği ise son yıllarda öne çıkan bir kavram olmuştur.

\subsection{Ambalaj ve İleri Dönüşüm}

Ambalaj, çevre ve sürdürülebilirlik açısından değerlendirildiğinde; geri dönüşüm, geri kazanım ve yeniden kullanım kavramları göze çarpmaktadır. Aynı konuda literatürde bulunan, ancak ambalaj tasarımı ile ilgili üzerine çok fazla çalışmaya rastlanmayan diğer kavram ise ileri dönüşümdür. İleri dönüşüm; artık işe yaramaz olan bir şeyi, işe yarar bir hale getirmektir.

İleri dönüşüm, geri dönüşüme göre daha çevreci ve faydalı bir yol sunmaktadır. Geri dönüşüm bir alternatif olsa da, geri dönüşümün enerji, su veya diğer kaynaklar gerektirdiğini unutmamak önemlidir. İleri dönüşüm, yeşil bir uygulama olarak da düşünülebilir. Bir tüketici bir şeyi ileri dönüştürdüğünde, onu atık sınıfına sokmak yerine, o öğeyi yeniden kullanır. Bir anlamda, ileri dönüşüm, ürünlere ölümden sonra yeni bir yaşam sunar ve bu nedenle ürünü "yeşilleştirme" yöntemidir. İleri dönüşüm sayesinde bir tüketici bir ürün için alternatif bir kullanım bulduğunda, gerekli işlevi yerine getirmek için alternatif bir ürün tüketmekten de kaçınması yanında tüketiciler bir ürünün potansiyel alternatif kullanımlarına dayanarak satın alma kararları verebilmektedir (Wilson, 2016: 7).

İleri dönüştürülebilen ambalaj kavramı; sürdürülebilir ambalajın yeniden kullanımında çokça bahsedilen aynı ambalajın ikinci, üçüncü kez kullanılmasından veya aynı ambalajın farklı bir fonksiyonda yeniden kullanılmasından daha ziyade kullanım ömrü biten ambalajın tamamına veya bir kısmına yeni ve ikincil bir fonksiyon yüklenerek, yani dönüştürülerek, yeniden ve farklı bir amaç için tekrar kullanılabilir olması ile açıklanabilir.

İleri dönüşümün tüketiciye sağladığı yararlar Tablo 4'de açıklanmıştır. Buna göre ileri dönüştürülebilen ambalaj/ürün kavramı ve tüketiciye sağladığ1 faydalar göz önüne alındığında, bir ürün ve pazarlama yeniliği olarak ambalajın ileri dönüştürülebilir özellikte tasarlanması, işletmeler açısından da rekabet avantajı yaratabilecektir.

Tablo 4. İleri Dönüşümün Tüketiciye Sağladığı Yararlar

\begin{tabular}{l|l}
\hline Estetik Cazibe & Tüketici, ileri dönüşümlü ürünlerin nostaljik, antik ya da retro görünümlerinden keyif alır. \\
\hline Ekonomik & $\begin{array}{l}\text { Tüketici, yeni bir ürün satın almak yerine, ürünün atığını başka bir kullanım amacına uygun } \\
\text { olacak şekilde dönüştürmenin ekonomik avantajından faydalanır. }\end{array}$ \\
\hline $\begin{array}{l}\text { Tasarruf } \\
\text { Faydalar }\end{array}$ & $\begin{array}{l}\text { Tüketici, bir ürünü atık sınıfına sokmak yerine ürünü başka bir amaç için kullanarak çevreci } \\
\text { bir fayda sağlar. }\end{array}$ \\
\hline Gerçek Zevk & Tüketici, atıkları dönüştürme, değiştirme ve uyumlulaştırma süreçlerinden keyif alır. \\
\hline
\end{tabular}

Kaynak: Wilson (2016: 7)

Ambalajın bir pazarlama bileşeni olarak ele alındığı, aynı zamanda yeni ve yaratıcı tasarımlarla tutundurmaya etki ederek ürün satın alma isteğini arttırıcı rol oynaması, ileri 
dönüşümlü ambalajın da tüketicinin satın alma isteğine etki etme olasılığını ortaya çıkarmıştır. $\mathrm{Bu}$ neticede, literatürde yeni bir kavram olarak ortaya çıkan ileri dönüşüm kavramı ile bütünleşen yenilikçi ambalaj tasarımına karşı tüketicinin satın alma niyetini anlamak, araştırmanın ana amacını oluşturmaktadır. İleri dönüşüm kavramının literatürde yeni olması sebebi ile çalışma görseller ve tanımlarla desteklenmiştir.

\subsubsection{Ambalajın İleri Dönüşümü ile Ambalaj Tasarımına Getirilen Yenilik ve Örnek Ambalaj Tasarımları}

Ambalajda ileri dönüşüm kavramının uygulandığı örnek ambalaj tasarımları Şekil 1-4 arasında sunulmuştur. Bu görsellerin tamamı, ambalajın ileri dönüşüm fonksiyonu göz önünde bulundurularak tasarlanan yenilikçi ve yaratıcı ambalaj örnekleridir. Ambalajın, içinde barındırdığ ömrü tamamen dolduktan sonra ikincil bir fonksiyon edinmesi mümkündür.

Şekil 1'de aydınlatma armatürünü oluşturan elektrik aksam, oluklu mukavvadan üretilen ambalaj içerisine yerleştirilmiştir. Ambalaj üzerine açılan boşluklarla yaratılan lamba formu, aydınlatma elemanının başlığını oluşturmakta; açılan boşluklardan sızan ışık ise gerekli aydınlatmayı sağlamaktadır. $\mathrm{Bu}$ sayede ürünün ambalajı ürünün fonksiyonunu gerçekleştirmesini sağlayan parçalardan biri haline gelmiştir.
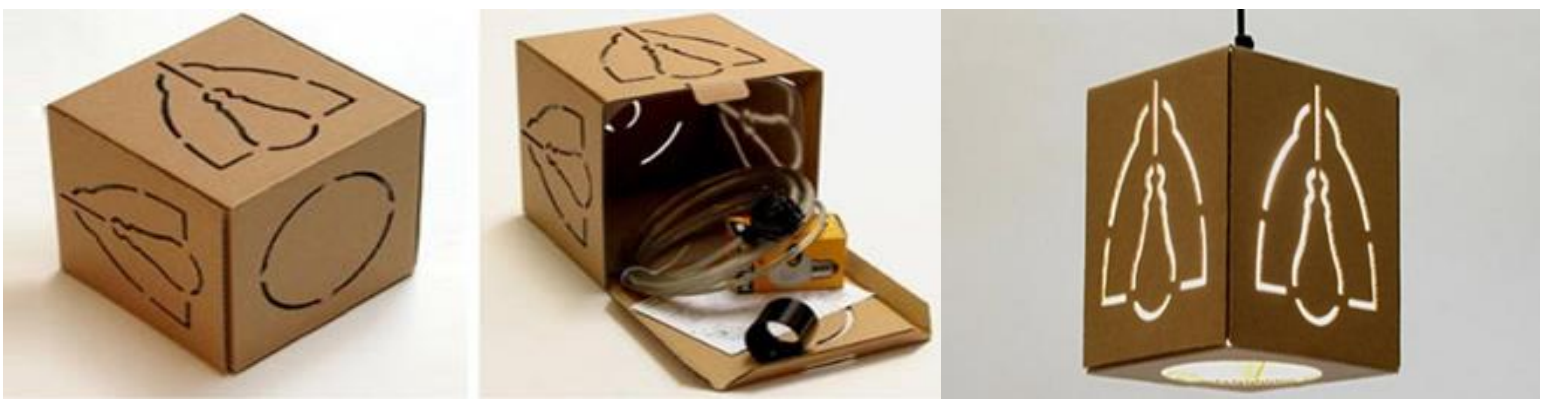

Şekil 1. Aydınlatma Armatürüne Dönüşen Lamba Ambalaj1

Kaynak: https://dornob.com/creative-cardboard-hanging-floor-table-lamp-designs/

Şekil 2'de beyaz bir kupanın ambalaj1; mantar malzemelerden birbirine geçmeli prizmatik bir yapı oluşturacak şekilde tasarlanmıştır. Tüketici, birbirine geçmeli parçaları ayırdı̆̆ında kupaya ulaşabilmekte, ayrılan ambalaj parçalarını ise bardakaltlığı olarak kullanabilmektedir. Ambalaj, ürünün kullanım esnasındaki sıcaklığının masaya geçmesini önleyen bir ayırıcı işlevi kazanmıştır.

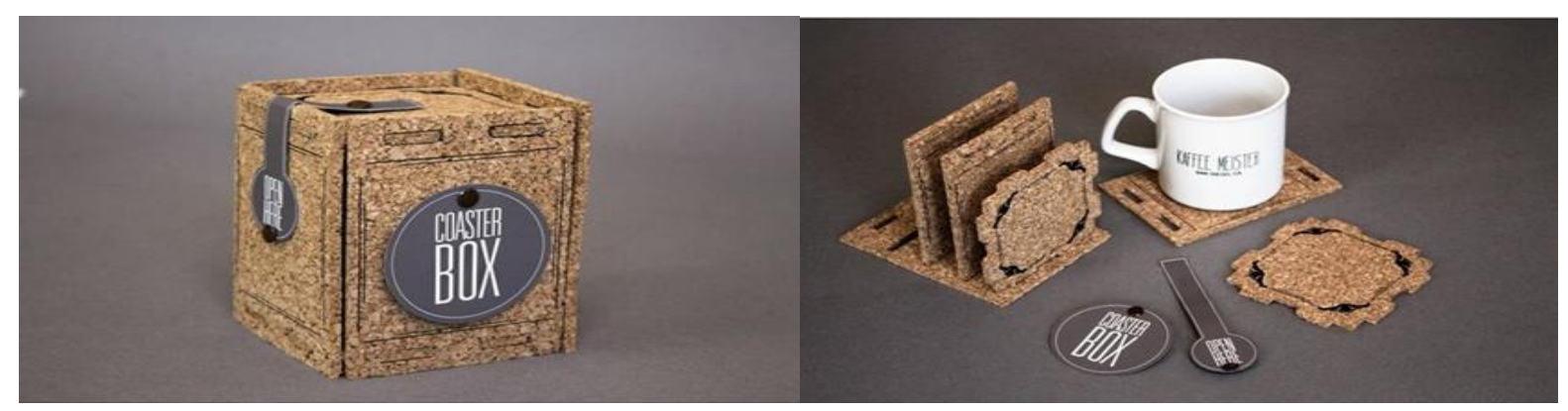

Şekil 2. Bardak Altlı̆̆ına dönüşen Kupa Ambalaj1

Kaynak: https://ar.pinterest.com/pin/118008452709641693/ 
Şekil 3'te geçmeli şekilde tasarlanan ve ahşaptan imal edilen şarap şişesi ambalajı, şarap şişelerini içerisinden aldıktan sonra farklı kesişim yerlerinden geçme sağlanarak kendi strüktürünü taşıyabilecek bir raf yapısına bürünmektedir. Bu sayede şarap şişeleri raf üzerinde hareketsiz durabilmektedir. Ambalaj, görsel zenginliğe sahip bir ürüne dönüştürülmüştür.

Şekil 4' te metalden imal edilen dekoratif çerçeveyi taşıyan oluklu mukavva ambalaj ve ambalaj üzerindeki grafik tasarımda kedi evi parçalarının baskısı görülmektedir. Tüketici çerçeveyi ambalajından çıkardıktan sonra oluklu mukavva üzerindeki baskılı bölümü keserek yedi ayrı parça elde etmekte ve bu parçaları birleştirerek bir kedi evi yaratabilmektedir. Diğer örneklerden farklı olarak bu ambalaj tasarımı ürünün fonksiyonuna katkı sağlamaktan ziyade tamamen yeni bir işlev kazanmıştır. Böylece, sosyal sorumluluk anlamında üretici firma imajına katkı sağlamakta ve tüketiciye yeni bir aktivite ile keyifli zaman geçirme olanağı sunmaktadır.
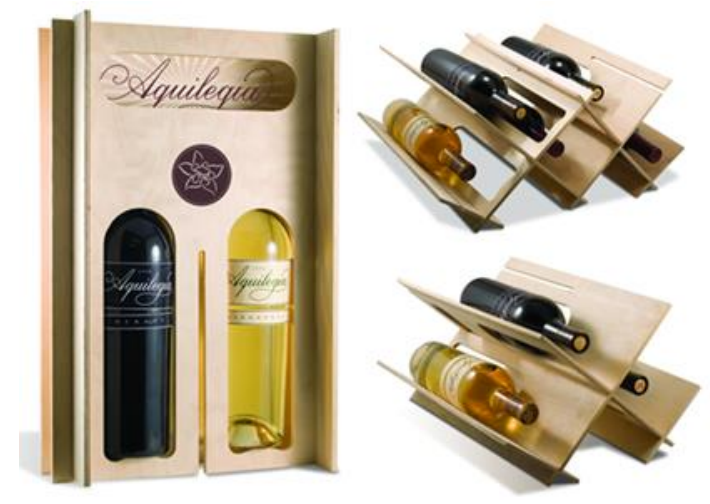

Şekil 3. Şarap Setine Dönüşen Şarap Ambalaj1

Kaynak: http://dcp-uk.co.uk/10-amazinglycreative-examples-product-packagingdesign/tresdon-wine-wooden-packaging-design/

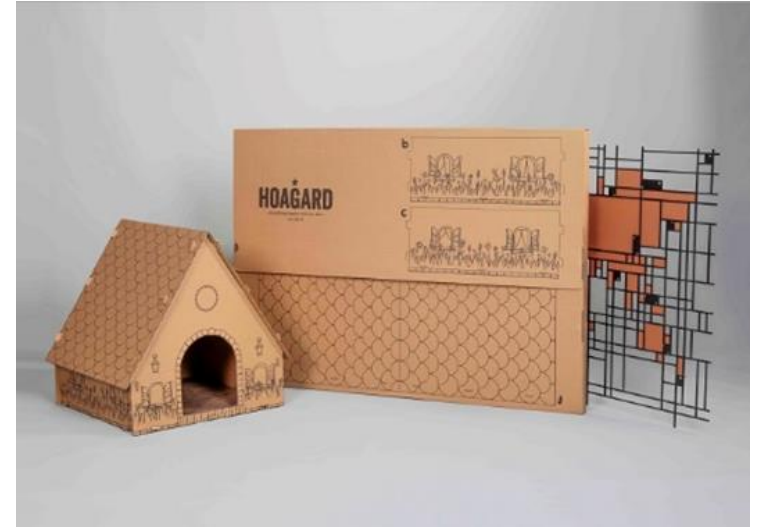

Şekil 4. Kedi Evine Dönüşen Metal Çerçeve Ambalaj1

Kaynak: https://www.hoagard.com/products/mondrianworld-map

Ambalajın ileri dönüştürülmesi aşamasında, ambalajın yeni bir ürün olarak tüketici ile etkileşime geçmesi ve tüketiciye yeni bir kullanıcı deneyimi yaşatmasından da bahsedilebilmektedir. Bu sebeple ambalajın ileri dönüştürülmesi esnasında tüketiciye düşen rol büyüktür. Ambalajın ileri dönüşümü, tüketiciyi de içine alan bir süreci ifade etmektedir. Tüketicinin bu konudaki tutumu ise oldukça önemlidir. Tüketici, ürüne ikincil bir fonksiyon eklemek isteyebilir veya istemeyebilir.

\section{YENILIKKÇi AMBALAJ TASARIMINA YÖNELIK TÜKETICİ TUTUMUNUN BELIRLENMESINE YÖNELIK BİR ARAŞTIRMA}

\subsection{Araştırmanın Amacı}

$\mathrm{Bu}$ araştırmada yenilikçi ambalaj tasarımı, ileri dönüşüm kavramına odaklanılarak analiz edilmiş, çevre ve sürdürülebilirlik kavramları ile birlikte ele alınmıştır. Araştırmanın amacı, (1) katılımcıların çevreye duyarlılıklarını belirlemek, (2) yeşil tüketici değerleri ve çevre bilinci ile satın alma davranışı arasındaki ilişkiyi ölçmek, (3) ambalajın özelliklerinin satın alma kararı 
ile ilişkisini ölçmek ve (4) katılımcıların ileri dönüşümlü ambalaja yönelik tutumunu ve (5) ileri dönüşümlü ambalajlı ürünlere yönelik satın alma niyetini belirlemektir. Bu çerçevede araştırmanın alternatif hipotezleri ise aşağıdaki gibi sıralanabilir.

H1: Tüketicilerin çevreye ilişkin kişisel değerleri yaşlarına göre farklılık göstermektedir.

H2: Tüketicilerin çevreye ilişkin kişisel değerleri ile çevre bilinci arasında pozitif yönlü bir ilişki vardır.

H3: Tüketicilerin çevreye ilişkin kişisel değerleri ile ileri dönüşümlü ambalaja ait ürün satın alma niyeti arasında pozitif yönlü bir ilişki vardır.

H4: Tüketicilerin çevre bilinci ile ileri dönüşümlü ambalaja ait ürün satın alma niyeti arasında pozitif yönlü bir ilişki vardır.

\subsection{Araştırmanın Önemi}

Çevresel değerlerin ve gelecek nesillere daha iyi bir dünya bırakabilmenin önemi her geçen gün artmakta ve hem üreticilerin hem tüketicilerin bu konuda git gide bilinçlendiği bir dünyada yaşamaktayız. Bu çalışmada tüketicilerin çevre bilinci ve sürdürülebilirlik ile ilgili tutumlarının ileri dönüşümlü ambalaj satın alma niyetine etkisi belirlenmiştir.

\subsection{Araştırmanın Yöntemi}

Araştırmada veri toplama yöntemi olarak anket yöntemi kullanılmış ve anketler internet üzerinden yapılmıştır. Anket formunda yer alan ölçeklerin ve bu ölçeklere ilişkin ifadelerin belirlenmesi için literatürden faydalanılmıştır. Anket formunda kullanılan ölçeklere ilişkin ifadeler hazırlanırken yeşil tüketici değerleri için Haws vd. (2014), çevre bilinci için Bohlen vd. (2010) ve ambalaj özellikleri için Aygün (2007) tarafından yapılan araştırmalardan yararlanılmıştır. Ancak, ileri dönüşümlü ambalaja yönelik satın alma niyetinin belirlenebilmesine yönelik sorular, literatürde yeterli bilgi olmaması nedeniyle tarafımızdan oluşturulmuştur.

Anket formu, ileri dönüşüm ve ileri dönüşümlü ambalaj hakkında bir tanım ile birlikte 4 farklı görsel ve açıklamalarından oluşan ilk sayfa ve bu açıklamaları takip eden 29 sorudan oluşturulmuştur. İlk 3 soru, katılımcıların demografik özelliklerini belirlenmesi, 6 soru katılımcıların çevreye ilişkin kişisel değerlerinin belirlenmesi, 6 soru katılımcıların çevreye ilişkin bilgilerinin belirlenmesi, 6 soru tüketicilerin ileri dönüşümlü ambalaja ait ürün satın alma niyetinin etkisinin belirlenmesine yönelik 5 noktalı likert ölçekli (1. Kesinlikle Katılmıyorum- 5. Kesinlikle Katılıyorum) olarak hazırlanmıştır. Son 8 soru ise ambalaj özeliklerinin katılımcların karar düzeyine etkisinin önem düzeyini belirlemek için oluşturulmuş ve 1 çok önemsizden - 5. çok önemliye kadar derecelenen 5 noktalı likert ölçek kullanılmıştır. Anket formu oluşturulma aşamasında soruların yanlış anlaşılmasını önlemek amacıyla 10 kişi üzerinde pilot uygulama yapılmış ve ambalaj özelliklerinin daha anlaşılır olabilmesi için özelliklere ait açılamalar parantez içerisinde belirtilmiştir. Kontrol amaçlı olarak 29 Sorudan 3 tanesi ankette olumsuz olarak sorulmuştur, analiz aşamasında soruların yönü değiştirilmiştir. İnternet üzerinden yapılan ankette cevaplayıcıların soru hakkında fikrinin olmaması ihtimali göz önüne alınarak sorulara cevap verme zorunluluğu koyulmamıştır. 
Araştırmanın ana kütlesini Türkiye'de satın alma davranışını gerçekleştiren tüketiciler oluşturmaktadır. Veriler, 18.05.2019 - 09.06.2019 tarihleri arasında kolayda örnekleme yöntemi ile seçilen 292 kişiden elde edilmiştir. Kontrol amaçlı sorulan 3 soruya verilen tutarsız cevaplar sebebi ile 39 adet analiz aşamasında çıkarılmış ve 253 anket SPSS 24.0 programı ile analize tabi tutulmuştur. Analizde nominal ölçekte hazırlanan sorular için frekans dağ̆lımları, aralıklı ölçekte hazırlanan sorular için aritmetik ortalama ve standart sapma değerleri hesaplanmış, veriler normal dağıldığ 1 için farklılığın belirlenmesinde parametrik testlerden ttesti ve tek yönlü varyans analizinden yararlanılmıştır.

Araştırma kapsamında oluşturulan ölçek değişkenlerinin güvenilirliklerinin değerlendirilmesi için Cronbach Alfa katsayısı kullanılmıştır. Cronbach Alfa katsayısının 0,60 'tan büyük olması ölçeğin güvenilirliğini göstermektedir. Buna göre ankette kullanılan ölçeklerin/boyutların güvenilirliğini gösteren bulgular Tablo 5'te yer almaktadır.

Tablo 5. Anketi Oluşturan Boyutların Madde Sayısı ve Cronbach Alpha Değerleri

\begin{tabular}{lcc}
\hline Ölçek Adı & Madde Sayısı & $\begin{array}{c}\text { Cronbach's Alpha } \\
\text { Katsayıs }\end{array}$ \\
\hline Yeşil Tüketici Değerleri & 6 & 0,694 \\
\hline Çevre Bilinci & 6 & 0,613 \\
\hline İleri Dönüşümlü Ambalaja Ait Ürün Satın Alma Niyeti & 6 & 0,666 \\
\hline Ambalaj Özellikleri & 8 & 0,735 \\
\hline
\end{tabular}

Araştırmada sadece internet erişimi olan tüketicilerin kullanılması araştırmanın kısıtlarından birini oluşturmaktadır. İnternet üzerinden oluşturulan anket verileri için 22 günlük bir süre ayrılabilmesi araştırmanın diğer bir önemli kısıtıdır. İleri dönüşüm konusunun literatürde yeni olması sebebi ile cevaplayıcıların konu hakkında sınırlı bilgisinin olma ihtimali araştırmanın kısıtlarından biri olup, anket formunda görseller ve açılamalar yer verilerek cevaplama aşamasından önce bilgi verilmesi amaçlanmıştır.

\subsection{Araştırmanın Bulguları}

Örneklemin demografik özelliklerine ait bulgular Tablo 6'da yer almaktadır. Buna göre araştırmaya katılan 141 kadın, örneklemin \%55,7'sini ve 112 erkek, örneklemin \%44,3'ünü oluşturmaktadır.

Tablo 6. Katılımcıların Demografik Özellikleri

\begin{tabular}{llllcc}
\hline Cinsiyet & $\mathbf{N}$ & $\mathbf{\%}$ & Eğitim & $\mathbf{N}$ & $\mathbf{\%}$ \\
\hline Kadın & 141 & 55.7 & İlköğretim & 5 & 2.0 \\
\hline Erkek & 112 & 44.3 & Lise & 37 & 14.6 \\
\hline Yaş & $\mathbf{N}$ & $\mathbf{\%}$ & Ön lisans & 30 & 11.9 \\
\hline $19-33$ & 147 & 58.1 & Lisans & 131 & 51.8 \\
\hline $34-48$ & 74 & 29.2 & Lisans Üstü & 50 & 19.8 \\
\hline 49 ve üzeri & 32 & 12.6 & & & \\
\hline
\end{tabular}

\%58.1 oranında ve 19-33 yaş aralığında 147 kişi, \%29.2 oranında ve 34-48 yaş aralığında 74 kişi ve \%12.6 oranında 49-76 yaş aralığında 32 katılımcı bulunmaktadır. Katılımcıların \%2'sini ilköğretim eğitim düzeyinde 5 kişi, \%14,6'sını lise eğitim düzeyinde 37 kişi, \%11,9'unu ön 
lisans eğitim düzeyinde 30 kişi, \%51,8'ini lisans eğitim düzeyinde 131 kişi ve \%19,8'ini lisansüstü eğitim düzeyinde 50 kişi oluşturmaktadır.

Yeşil tüketici değerleri ve çevre bilinci ifadelerine ait ortalamalar ve standart sapmalar Tablo 7'deki gibidir:

Tablo 7. Yeşil Tüketici Değerleri ve Çevre Bilinci İfadelerine Ait Ortalamalar ve Standart Sapmalar

\begin{tabular}{|c|c|c|}
\hline Yeşil Tüketici Değerleri & $X^{-}$ & SD \\
\hline a. Kullandığım ürün ve ambalajların çevreye zarar vermemesi benim için önemlidir. & 4.61 & 0.571 \\
\hline b. Günlük hayatımın çevre üzerindeki potansiyel etkilerini göz önünde bulundururum. & 4.31 & 0.678 \\
\hline c. Satın alma alışkanlıklarım çevre için taşıdığım kaygılardan etkilenir. & 3.77 & 0.831 \\
\hline d. Dünyamızın doğal kaynaklarının boşa harcanması konusunda endişeliyim. & 4.77 & 0.434 \\
\hline e. Karton ambalaj atıklarımı geri dönüşüm kutusuna atarım. & 4.21 & 0.950 \\
\hline f. Çevre dostu faaliyetler için zahmete girmek istemem. (ters kodlama yapılmıştır) & 4.29 & 0.876 \\
\hline \multicolumn{3}{|l|}{ Çevre Bilinci } \\
\hline g. Küresel ısınma doğal hayatı tehdit eden bir faktördür. & 4.81 & 0.449 \\
\hline h. İçme sularının kirlenmesi insan hayatını tehdit eden bir faktördür. & 4.92 & 0.285 \\
\hline i. Lamba ve elektronik aletleri sadece ihtiyaç duyduğumda açık bırakırım. & 4.48 & 0.770 \\
\hline j. $\quad$ Kişisel bakımımı yaparken su kullanımına dikkat ederim. & 4.28 & 0.847 \\
\hline k. Herhangi bir çevre sorunu görmüyorum. & 4.80 & 0.455 \\
\hline 1. Bir dokümanın çıktısını almak yerine bilgisayar ortamında okumayı tercih ederim. & 3.88 & 1.092 \\
\hline
\end{tabular}

Tablo 7'deki ifadelere verilen cevapların genel olarak ortalaması 4.40'ın üzerindedir. Verilen cevaplarda Katılıyorum ve Kesinlikle Katılıyorum ifadelerinin daha çok yer aldığ1 görülmektedir. Tüketici değerleri ölçeğinde bulunan kullandığım ürün ve ambalajların çevreye zarar vermemesi benim için önemlidir ifadesine katılımın 4.61 ortalama ve 0.571 standart sapma ile oldukça yüksek olduğu görülmektedir. Çevre bilincine ait ifadelerde ise katılımcıların küresel ısınma, içme sularının kirlenmesi gibi çevresel tehditlere karşı farkındalığa sahip olduğu yorumu yapılabilir.

İleri dönüşümlü ambalaja ait ürün satın alma niyeti ifadelerine ait ortalamalar ve standart sapmalar Tablo 8' deki gibidir:

Tablo 8. İleri Dönüşümlü Ambalaja Ait Tutum ve Ürün Satın Alma Niyeti İfadelerine Ait Ortalamalar ve Standart Sapmalar

\begin{tabular}{clcc}
\hline \multicolumn{2}{l}{ İleri Dönüşümlü Ambalaja Ait Ürün Satın Alma Niyeti } & $X^{-}$ & SD \\
\hline a. & Benzer fiyata sahip ürünlerden ileri dönüşümlü ambalajı olan ürünleri tercih ederim. & 4.04 & 0.894 \\
\hline b. Ambalajı başka işlerde tekrar kullanmak istemem. (ters kodlama yapılmıştır) & 4.03 & 0.967 \\
\hline c. & Ambalajı yeniden kullanmak için biraz uğraş gerekiyorsa, bunu yapabilirim. & 4.04 & 0.842 \\
\hline d. İleri dönüşümlü ambalaja sahip bir ürünü deneyimlemek isterim. & 4.41 & 0.750 \\
\hline e. Ürün ambalajına getirilen yenilikler satın alma isteğimi arttırır. & 3.81 & 1.166 \\
\hline f. & Ileri dönüşümlü ambalaja sahip ürünleri market raflarında görmek isterim. & 4.60 & 0.657 \\
\hline
\end{tabular}

Tablo 8' de katılımcıların ileri dönüşümlü ambalaja sahip olan ürünleri satın alma niyetlerine ait ifadelere verilen cevapların aritmetik ortalamaları ve standart sapmaları bulunmaktadır. İfadelere verilen cevapların genel olarak ortalaması 4.15 in üzerindedir. Verilen cevaplarda Katılıyorum ve Kesinlikle Katılıyorum ifadelerinin daha çok yer aldı̆̆ görülmektedir. Katılımcıların benzer fiyata sahip ürünlerden ileri dönüşümlü ambalajı olan ürünleri tercih 
etmeleri, ambalajı başka işlerde tekrar kullanmak istemeleri, ileri dönüşümlü ambalaja sahip bir ürünü deneyimleme isteğinin yüksek olması ve ileri dönüşümlü ambalaja sahip ürünleri market raflarında görmek istemelerinden dolayı ileri dönüşüme yönelik olumlu bir tutuma sahip olduğu, ancak ürün ambalajına getirilen yeniliklerin satın alma isteğini kısmen arttırdığ 1 sonucuna ulaşılmıştır.

Ambalaj özellikleri ile ilgili ifadelere ait ortalamalar ve standart sapmalar Tablo 9'da sunulmuştur. Buna göre, katılımcıların ambalaj özelliklerine ait önem düzeyi ifadelerine verilen cevapların aritmetik ortalamaları ve standart sapmaları bulunmaktadır. Katılımcılar için ambalajın ürünü koruması, çevre dostu olması, ürünü saklaması ve ürün hakkında bilgilendirici olması çok önemli olarak nitelendirilmektedir. Ambalajın kolay kullanılması ve ileri dönüştürülebilir olması da katılımcılar tarafından önemli olarak ifade edilmiştir. Ambalajın görsel güzelliği ve ürün fiyatını arttıracak şekilde olmaması ifadelerinin ise önem düzeyinin diğer ifadelere göre daha düşük olduğu görülmüştür.

Tablo 9. Ambalaj Özellikleri İle İlgili İfadelere Ait Ortalamalar ve Standart Sapmalar

\begin{tabular}{llcc}
\hline \multicolumn{2}{l}{ Ambalaj Özellikleri } & $X^{-}$ & SD \\
\hline a. & Ürünü koruması (Ürünü dış etkenlerden koruma) & 4.61 & 0.578 \\
\hline b. & Ürünü saklaması (Ürünü bir sonraki kullanım için muhafaza etme) & 4.54 & 0.645 \\
\hline c. & Kolay kullanılması (Kolay açılabilir kapak, taşıyıcı sap kullanımı vb.) & 4.49 & 0.602 \\
\hline d. & Çevre dostu olması (Çevreye zararı olmayan malzeme kullanımı, geri dönüştürülebilir) & 4.57 & 0.611 \\
\hline e. & İleri dönüştürülebilir olması (Ambalajın farklı bir amaçla yeniden kullanılması) & 4.36 & 0.719 \\
\hline f. & Çekici renk ve biçimde olması (Ambalajın görsel güzelliği) & 3.34 & 1.190 \\
\hline g. & Ürünün fiyatını arttıracak şekilde olmaması (ters kodlama yapılmıştır) & 4.18 & 0.921 \\
\hline h. & Ürün hakkında bilgilendirici olması (Kullanıma, saklamaya ait bilgilerin bulunması) & 4.54 & 0.685 \\
\hline
\end{tabular}

Araştırmada çevre bilincinin, yeşil tüketici değerlerinin ve ambalaj özelliklerine ilişkin önem düzeyi ifadelerinin yaşa göre değişiklik gösterip göstermediği ile ilgili belirlenmek istenen "H1: Tüketicilerin çevreye ilişkin kişisel değerleri yaşlarına göre farklılık göstermektedir" alternatif hipotezi tek yönlü varyans analizi (one way Anova) ile test edilmiştir.

Tablo 10. Yaşa Göre Araştırmaya Katılan Tüketicilerin Yeşil Tüketici Değerlerine İfadelerine İlişkin ANOVA Tablosu

\begin{tabular}{|c|c|c|c|c|c|c|}
\hline & & $\begin{array}{c}\text { Kareler } \\
\text { Toplamı }\end{array}$ & $\begin{array}{c}\text { Serbestlik } \\
\text { Derecesi }\end{array}$ & $\begin{array}{c}\text { Kareler } \\
\text { Ortalaması }\end{array}$ & $\mathbf{F}$ & $\mathrm{p}$ \\
\hline \multirow{3}{*}{$\begin{array}{l}\text { Yeşil Tüketici } \\
\text { Değerleri }\end{array}$} & Gruplar Arası & 3.479 & 2 & 1.740 & \multirow{3}{*}{9.832} & \multirow{3}{*}{.001} \\
\hline & Grup İçi & 44.235 & 250 & .177 & & \\
\hline & Toplam & 47.714 & 252 & & & \\
\hline
\end{tabular}

Tablo 11. Çoklu Karşılaştırma (Yaş Grupları ve Yeşil Tüketici Değerleri)

\begin{tabular}{|c|c|c|c|c|c|c|c|}
\hline \multicolumn{8}{|c|}{ Tukey HSD } \\
\hline $\begin{array}{c}\text { (I)Yaş } \\
\text { Grupları }\end{array}$ & Ortalama & $\begin{array}{c}\text { (J)Yaş } \\
\text { Grupları }\end{array}$ & $\begin{array}{l}\text { Ortalama } \\
\text { Farkı (I-J) }\end{array}$ & $\begin{array}{c}\text { Standart } \\
\text { Hata }\end{array}$ & p & $\begin{array}{c}\text { Alt } \\
\text { Limit }\end{array}$ & Üst Limit \\
\hline \multirow{2}{*}{$19-33$} & \multirow{2}{*}{4.2531} & $34-48$ & -.09379 & .05996 & .263 & -.2351 & .0476 \\
\hline & & $49-76$ & $-.36152^{*}$ & .08205 & .001 & -.5550 & -.1681 \\
\hline \multirow{2}{*}{$34-48$} & \multirow{2}{*}{4.3468} & $19-33$ & .09379 & .05996 & .263 & -.0476 & .2351 \\
\hline & & $49-76$ & $-.26774^{*}$ & .08900 & .008 & -.4776 & -.0579 \\
\hline \multirow{2}{*}{$49-76$} & \multirow{2}{*}{4.6146} & $19-33$ & $.36152^{*}$ & .08205 & .001 & .1681 & .5550 \\
\hline & & $34-48$ & $.26774^{*}$ & .08900 & .008 & .0579 & .4776 \\
\hline
\end{tabular}


Tablo $10^{\prime}$ da F=9.832 ve ( $\left.\mathrm{p}=0.000\right)$ p değerinin $0.5^{\prime}$ ten küçük olduğu görülmektedir. Bu sebeple yeşil tüketici değerleri, tüketicilerin yaş gruplarına göre farklılık göstermektedir. Tablo 11'de yapılan Post Hoc Tukey analizi sonuçlarına göre 19-33 yaş arası katılımcıların yeşil tüketici değerleri, 34-48 yaş arası katılımcılardan daha düşük, 34-48 yaş arası katılımcıların yeşil tüketici değerleri ise 49-76 yaş arası katılımcılardan daha düşüktür. Bu durumda, yaşı 49'dan fazla olan tüketicilerin yeşil tüketici değerlerinin en yüksek olduğu sonucuna varılabilir. Buna göre H1 kabul edilmiştir.

Araştırma kapsamında incelenmek istenen konulardan bir tanesi de tüketicilerin ileri dönüşümlü ambalaja sahip ürün satın alma niyeti ile çevre bilinci ve çevreye ilişkin kişisel değerlerinin bir ilişkisi olup olmadığıdır. Tablo 12' deki Korelasyon analizi sonucuna göre tüm değişkenlerin birbirleri ile çok kuvvetli olmasa da ilişkili olduğu görülmektedir. Korelasyon analizi, iki değişken arasındaki ilişkiyi test etmek, varsa bu ilişkinin derecesini ölçmek için kullanılan istatistiksel bir yöntemdir. Korelasyon analizinde amaç, bağımsız değişken (x) değiştiğinde, bağımlı değişkenin (y) ne yönde değişeceğini görmektir. Korelasyon analizinde istatistiksel olarak anlamlı bir ilişki olabilmesi için p değerinin 0,05 'ten küçük olması beklenir. Buna göre, yeşil tüketici değerleri ve çevre bilinci arasında p değeri 0.001 olduğu için anlamlı bir ilişki bulunmaktadır. Ancak, Pearson korelasyon değeri 0.441 olduğundan pozitif yönlü doğrusal bir ilişki vardır, ancak çok güçlü değildir. Yeşil tüketici değerleri ve ileri dönüşümlü ambalaja sahip ürün satın alma niyeti arasında p değeri 0.001 olduğu için anlamlı bir ilişki vardır. Pearson korelasyon değeri 0.399 olduğundan pozitif yönlü doğrusal bir ilişki vardır, ancak çok güçlü değildir.

Tablo 12. Ölçek Değişkenlerine Ait Korelasyon Analizi

\begin{tabular}{|c|c|c|c|c|c|}
\hline & & $\begin{array}{c}\text { Yeşil } \\
\text { Tüketici } \\
\text { Değerleri } \\
\end{array}$ & $\begin{array}{l}\text { Çevre } \\
\text { Bilinci }\end{array}$ & $\begin{array}{l}\text { İleri Dönüşümlü } \\
\text { Ambalaja Ait Ürün } \\
\text { Satın Alma Niyeti }\end{array}$ & $\begin{array}{c}\text { Ambalaj } \\
\text { Özellikleri }\end{array}$ \\
\hline \multirow{3}{*}{$\begin{array}{l}\text { Yeşil Tüketici } \\
\text { Değerleri }\end{array}$} & Pearson Korelasyonu & 1 & $.441^{* *}$ & $.399^{* *}$ & $.282^{* *}$ \\
\hline & Sig. (2-kuyruklu) & & .001 & .001 & .001 \\
\hline & $\mathrm{N}$ & 253 & 253 & 253 & 253 \\
\hline \multirow{3}{*}{ Çevre Bilinci } & Pearson Korelasyonu & $.441^{* *}$ & 1 & $.309^{* *}$ & $.277^{* *}$ \\
\hline & Sig. (2-kuyruklu) & .001 & & .001 & .001 \\
\hline & $\mathrm{N}$ & 253 & 253 & 253 & 253 \\
\hline \multirow{3}{*}{$\begin{array}{l}\text { İleri Dönüşümlü } \\
\text { Ambalaja Ait } \\
\text { Ürün Satın Alma } \\
\text { Niyeti }\end{array}$} & Pearson Korelasyonu & $.399^{* *}$ & $.309^{* * *}$ & 1 & $.357^{* *}$ \\
\hline & Sig. (2-kuyruklu) & .001 & .001 & & .001 \\
\hline & $\mathrm{N}$ & 253 & 253 & 253 & 253 \\
\hline \multirow{3}{*}{$\begin{array}{l}\text { Ambalaj } \\
\text { Özellikleri }\end{array}$} & Pearson Korelasyonu & $.282^{* *}$ & $.277^{* *}$ & $.357^{* *}$ & 1 \\
\hline & Sig. (2-kuyruklu) & .001 & .001 & .001 & \\
\hline & $\mathrm{N}$ & 253 & 253 & 253 & 253 \\
\hline
\end{tabular}

** Korelasyon anlamlılık düzeyi 0,05 (2-kuyruk)

Çevre bilinci ve ileri dönüşümlü ambalaja sahip ürün satın alma niyeti arasında p değeri 0.000 olduğu için anlamlı bir ilişkiden söz etmek mümkündür. Pearson korelasyon değeri 0.309 olduğundan pozitif yönlü doğrusal bir ilişki vardır, ancak çok güçlü değildir. Sonuç olarak $\mathrm{H} 2, \mathrm{H} 3$ ve $\mathrm{H} 4$ kabul edilmiştir. 


\section{SONUÇ}

Ambalaj tasarımında yapılan yenilikler, işletmelerin yoğun rekabet ortamında bir adım öteye gidebilmek için önem verdikleri bir unsur haline gelmiştir. Günümüzde çevre sorunlarının baş göstermesi, tüketicilerin çevre ve sürdürülebilirlik hakkında daha fazla bilinç kazanması, tüketicileri satın aldıkları ürünlerde de daha çevreci yaklaşımlar sergilemeye itmiştir.

Ambalaj tasarımlarına getirilen fonksiyonel ve estetik yenilikler, tüketicinin dikkatini çekmekte ve işletmeler için bir rekabet aracı olarak kullanılabilmektedir. Yenilikçi ambalaj tasarımı olarak da nitelendirebileceğimiz ve henüz literatürde yer almayan ileri dönüşümlü ambalaj ise ambalajı hem çevre hem de sürdürülebilirlik açısından daha değerli kılmaktadır. Bunun sebebi, ileri dönüşümün geri dönüşümden farklı olarak atık haline gelen bir nesneyi yeniden farklı bir amaçla kullanma olanağı sunmasıdır.

Araştırma kapsamında ileri dönüşüm kavramının ambalaj tasarımlarında uygulanan ve bu kavram ışığında tasarlanan ambalajlı ürünlerin tüketicilerin satın alma niyetini nasıl etkilediği araştırılmıştır. Bu sebeple, öncelikle katılımcıların çevreye ilişkin bilgileri ve çevreye ilişkin kişisel değerleri incelenmiştir. Çevreye ilişkin kişisel değerler ve çevreye ilişkin bilgi arasında pozitif yönlü bir ilişki bulunmuştur. Aynı zamanda çevreye ilişkin bilgi ve kişisel değerlerin yaş gruplarına göre farklılaştığı ortaya çıkmıştır. Yaş ilerledikçe artan çevre bilincinin, çevreye ilişkin kişisel değerleri arttırma ihtimali olduğundan söz etmek mümkün olmuştur.

Çevreye ilişkin bilgi ve kişisel değerlerin ise ileri dönüşümlü ambalaja ait ürün satın alma niyeti ile pozitif yönlü bir ilişkisinin olduğu bulunmuştur. Çevreye ilişkin bilinç ve yeşil tüketici değerleri arttıkça ileri dönüşümlü ambalaja sahip ürün satın alma niyetinin de artış göstermesi söz konusudur.

Tüketiciler, ürünle birlikte satın aldıkları ambalajın ürünü korumasını, saklamasını, çevre dostu olmasını, kolay kullanılmasını ve bilgilendirici nitelikte olmasını beklemektedirler. Ambalajın tüm bu işlevleri ile birlikte ileri dönüştürülebilir olmasını da bekleyen ve bu tip ürün ve ambalajları kullanıp deneyimlemek isteyen tüketici yüzdesi yapılan araştırmaya göre oldukça fazladır. Bu durum sonucunda tüketicilerin çevreye ilişkin bilgi ve kişisel değerleri gün geçtikçe artış gösterdiğinden, ileri dönüşümlü ambalaja sahip ürün satın alma niyetlerinde de zamanla artış görülmesi mümkündür. Yenilikçi bir pazarlama ve ambalaj tasarımı stratejisi olarak literatürde kendine yer edinebilecek olan ileri dönüşümlü ambalajların, işletmelerin rakipleri ile rekabet edebilmelerinde de önemli bir unsur olarak ortaya çıkması muhtemeldir.

\section{KAYNAKÇA}

Altunışık, R., Özdemir, Ş., \& Torlak, Ö., (2016). Pazarlama İlkeleri ve Yönetimi, İstanbul: Beta Yayıncilik, 339-361.

Ambalaj Atıklarının Kontrolü Yönetmeliği (2017). Resmî Gazete Tarihi: 27.12.2017 Resmî Gazete Say1s1: 30283 
Ambalaj Bülteni, (2010). http://www.ambalaj.org.tr/files/ambalajbulteniicerik/dosya/ocaksubat-2010-dosya.pdf (18.05.2019).

Arköse, O. (2004). Yaratıcılığa ve Yeniliğe Yönlendirici Örgüt Yapısı. Yüksek Lisans Tezi, Dokuz Eylül Üniversitesi, Sosyal Bilimler Enstitüsü, İşletme Ana Bilim Dalı.

Arslan, H., \& Barutçu, S. (2019). Ambalaj Tasarımında Yenilik ve Yenilikçi Ambalaj Tasarımına Yönelik Tüketici Tutumu ve Satın Alma Niyetine Etkisi. XIII. IBANESS Congress Series on Economics, Business and Management - Tekirdag-Fall / Turkey, October 5-6, 2019, pp. 256-267.

Aygün, E. (2007). Ambalajın Tüketici Satın Alma Davranışı Üzerindeki Etkisi: Gıda Maddeleri Üzerinde Bir Araştırma. Sakarya Üniversitesi, Sosyal Bilimler Enstitüsü, İşletme Ana Bilim Dalı.

Barutçu, S., \& Tomaş, M. (2013). Sürdürülebilir Sosyal Medya Pazarlaması ve Sosyal Medya Pazarlaması Etkinliğinin Ölçümü. İnternet Uygulamaları ve Yönetimi Dergisi, 4(1), 5-23.

Bohlen, G., Schlegelmilch, B., \& Diamantopoulos, A. (2010). Measuring Ecological Concern: A Multi-Construct Perspective. Journal of Marketing Management, 9(4), 415-430.

Bülbül, H. (2003). Rekabet Üstünlüğü Sağlamada Ürün ve Süreç Yeniliği: Bilişim Teknolojileri Uygulaması. Doktora Tezi, Selçuk Üniversitesi, Sosyal Bilimler Enstitüsü, İşletme Ana Bilim Dalı.

Dijital Creative Packaging (2017). http://dcp-uk.co.uk/10-amazingly-creative-examplesproduct-packaging-design/tresdon-wine-wooden-packaging-design/ (14.05.2019)

Dornob Staff, https://dornob.com/creative-cardboard-hanging-floor-table-lamp-designs/ (10.05.2019)

Elçi, Ş. (2007). İnovasyon Kalkınmanın ve Rekabetin Anahtarı. Technopolis Group (2.Baskı).

Erkınay, B. (1996). Gıda Ürünlerinde Ambalajın Tüketici Algılaması Üzerindeki Etkisi. Yüksek Lisans Tezi, İstanbul Teknik Üniversitesi, Sosyal Bilimler Enstitüsü, İstanbul.

Grundey, D. (2010). Functionality of Product Packaging: Surveying Consumers' Attitude Towards Selected Cosmetic Brands. Economics \& Sociology, 3(1), 87-103.

Hair, J. F., Black, W. C., Babin, B. J., Anderson, R. E., \& Tatham, R. L. (2013). Multivariate Data Analysis: Pearson Education Limited

Haws,K., Winterich, K. \& Naylor, R. (2014). Seeing the world through GREEN-tinted glasses: Green consumption values and responses to environmentally friendly products. Journal of Consumer Psychology, 336-354.

Hoagard, https://www.hoagard.com/products/mondrian-world-map (14.05.2019)

Hongkiat, https://ar.pinterest.com/pin/118008452709641693/ (10.05.2019)

James, K., Fitzpatrick, L., Lewis, H., \& Sonneveld, K. (2005). Sustainable Packaging System Development. In Leal Filho, W. (ed) Handbook of Sustainability Research Peter Lang Scientific Publishing, Frankfurt. 
Karaca, Ş. (2013). Tüketicilerin Yeşil Ürünlere İlişkin Tutumlarının İncelenmesine Yönelik Bir Araştırma. Ege Akademik Bakış, 13(1), 99-111.

Kotler, P. (1988). Marketing Management. Englewood Cliffs, NJ: Prentice-Hall

OECD (2005), Oslo Kılavuzu, TÜBİTAK, (3.Baskı).

Övünç, S. (2015). Tüketicilerin Sürdürülebilir Ambalaja Ait Ürün Satın Alma Niyeti. Yüksek Lisans Tezi, İstanbul Teknik Üniversitesi, Fen Bilimler Enstitüsü, İşletme Mühendisliği Ana Bilim Dalı.

Özesen, E. (2009). Yeşil Tedarik Zinciri Yönetimi ve Ambalaj Sanayiinde Bir Uygulama. Yüksek Lisans Tezi, Marmara Üniversitesi, Sosyal Bilimler Enstitüsü, İşletme Ana Bilim Dalı.

Özgen, C. (2013). Sürdürülebilirlik Kavramının Firma Stratejisi Açısından Ambalaj Tasarımına Etkilerinin İncelenmesi. Doktora Tezi, İstanbul Teknik Üniversitesi, Fen Bilimleri Enstitüsü, Endüstri Ürünleri Tasarımı Ana Bilim Dalı.

Şen, M. (2007). Ambalaja Yönelik Tüketici Tutumları ve Bir Uygulama. Yüksek Lisans Tezi, Marmara Üniversitesi, Sosyal Bilimler Enstitüsü, İşletme Ana Bilim Dalı.

Tek, Ö. B. (1999). Pazarlama ilkeleri. 8. İstanbul: Beta Yayınları.

Türk, M. (2019). Yeşil Tüketici. Ankara: Nobel Akademik Yayıncılık

Uyar, A., \& Kılıçaslan, K. (2015). Yenilikçi İşletmelerin Tüketici Tercihleri Üzerindeki Etkisi: Dizüstü Bilgisayar Kullanıcıları Üzerine Bir Araştırma. Journal of Management, Marketing and Logistics, 2(2), 158-177.

Üçüncü, M. (2000). Gıdaların Ambalajlanması. İzmir: Ege Üniversitesi Basımevi.

Wilson, M. (2016). When Creative Consumers Go Green: Understanding Consumer Upcycling. Journal of Product \& Brand Management, 25(4), 394-399. 